\title{
Cross-Sector Collaboration and Public Policy Accountability: Implementation Network of Food Security Policy in Bone Regency ${ }^{1}$
}

\author{
Alwi $^{1}$, A. Aslinda ${ }^{2}$, Gita Susanti ${ }^{3}$ \\ 1Departement of Public Administration, Faculty of Social and Political Sciences, Universitas Hasanuddin \\ (email:alwifisip@gmail.com),2Departement of Public Administrative Science, Faculty of Social Sciences, \\ Universitas Negeri Makassar (email:aslinda110@yahoo.com), ${ }^{3}$ Departement of Public Administration, Faculty of \\ Social and Political Sciences, Universitas Hasanuddin (email:gitasusanti65@gmail.com)
}

\begin{abstract}
Public policy accountability is one of the essential concepts in public policy study, as it is a parameter to assess the performance of policymakers and implementers. The primary purpose of this study is 1) to know the performance of the implementation of food security policy; 2) to understand the cross-sector collaboration process as a strategy of public policy accountability. Based on the matching pattern and time series techniques, food policy accountability is still low in Bone Regency. This accountability issue happens because the performance of food policy implementers is still weak, and the cross-sector collaboration process has not been effective. Therefore, the forging agreement, building leadership, building legitimacy, building trust, managing conflict, and planning need to be considered to improve food policy accountability in Bone Regency.
\end{abstract}

\section{Keywords:}

cross-sector collaboration; public policy accountability; policy implementation network; food security policy

\section{Introduction}

One of the main objectives of public policy is to solve public problems (Smith \& Larimer, 2009). The public official who are given the authority to make policy always try to understand public issues. This happens because many public policies have failed to solve public problems, due to the fact that the problem is complex. For instance, stakeholders are still debating the definition and resolution of the problems - wicked problems.

Public policy accountability can be assessed from the resolution of public problems through these policy interventions. This shows that the scope of public policy accountability is not only the design of the policy but also at the implementation stage of the policy. To find out whether a public policy has succeeded or failed to meet the expectations of its target group can be seen at the stage of policy implementation.

\footnotetext{
${ }^{1}$ Annual Conference IAPA \& AGPA, Bali, 11-12 November 2019
} 
This study focuses on the implementation and assessment of the accountability of public policy. This stage is a stage of assessing the performance of as well as collaboration between stakeholders to achieve the objectives. A public policy implemented by a government agency has a relationship with other government institutions in its implementation. A government agency as the leading sector of a policy, needs to collaborate with other institutions to achieve the performance. This shows the complexity of public policy implementation (Pressman \& Wildavsky, 1984; Goggin et al., 1990) and the same time, shows the complexity of public policy accountability.

One of the public policies that became the focus of this study is the food security policy. This policy aims, as in Law No. 18 of 2012, concerning Food, to realize the availability of food for households in sufficient quantities, quality and proper nutrition, safe for consumption evenly and affordable by an individual. But until the third quarter of 2016, Indonesia has brought in 1.1 million tons of rice from abroad with a value of US \$ 472.5 million. While in the same period last year, the amount was only 229.6 thousand tons, with a value of US \$ 99.8 million. In this case, rice imports experienced a 46 percent increase, mostly from Thailand, Vietnam and Pakistan (Performance Report of the Food Security Agency, 2016).

Based on Centre Bureau of Statistics (BPS) 2015, Indonesia's population is 257.9 million, and it is estimated that Indonesia's population will increase to 273.1 million by 2025 . Indonesia's growth rate is predicted to increase by $1 \%$ annually. Based on the increase in population, it has the potential to cause a food crisis. The high growth of population leads to higher demand for food and when this is not matched by an increase in the production of food commodities, the food crisis is likely to occur.

The phenomenon shows the complexity of the implementation of the food security policy. The policy involves various stakeholders where they have competing interests and often conflict with each other. On the one hand, the target group is lower-income and marginalized communities in terms of economy and politics. On the other hand, implementers (government bureaucracy) always attempt to run this policy effectively and efficiently. Then, other stakeholders (private/traders) always attempt to get a lot of profit. This phenomenon shows the complexity of the implementation of public policy that leads to the understanding that the success of such implementation varies greatly between one place 
at different times (Goggin et al., 1990). Therefore, this study focuses on the accountability of the implementers of food security policy in Bone Regency, South Sulawesi Province.

Accountability is a concept that has a vast scope and, therefore, the experts provide meaning based on their perspectives and even conflict (Bovens, 2006; Mulgan 2005; Dwivedi \& Jabra, 1989). Bovens (2006) describes accountability as social relations so that it defines "as a relationship between an actor and a forum, in which the actor has an obligation to explain and to justify his or her conduct, the forum can pose questions and pass judgment, and the actor may face consequences. "Then, Dwivedi \& Jabra (1989) define" public service accountability involves the methods by which a public agency or public official fulfills its duties and obligations, and the process by which the agency or the public official is required to account for such actors." Both meanings show fundamental differences; the first mentioned is focuses on social relations, and the latter emphazises more on the methods and processes of accountability itself. Such differences encourage Finer (Denhardt \& Denhardt, 2007) defines accountability as differing from role to role, time to time, place to place, and from speaker to speaker. The difference thus causes no agreement on standards for accountable behavior.

In addition to the differences in terms of definition, there are also differences in the perspective of accountability. This can be shown in the debate Finer and Frederick (Denhardt \& Denhardt, 2007). According to Frederick, public officials are accountable when the implementers become professional and have specialized knowledge and technical expertise. This is based on the idea that the policy formulation process is entirely separate from the implementation. Therefore, the accountability of public officials is largely determined by their ability to achieve an efficient policy goal based on their professional knowledge and behavioral norms.

Instead, according to Finer (Denhardt \& Denhardt, 2007), public officials will be accountable when they controlled by elected officials (external control) in the policy implementation process. They represent the citizens, which their main task is to control the state apparatus in order to deliver public services following the needs and interests of citizens. External control is showed democratic values in the civil service. It shows that the public Officials should be subordinate from the elected officials, so they should hear the command to meet the needs and interests of the public. 
According to Erkkilla (2007), there is a new alternative in the study of public accountability, namely performance and deliberative accountability. The public officials will be accountable when they can be responsive to the output-oriented. It shows, it is more focuses on performance, and it means efficiency. Later, another alternative offered is deliberative accountability. Public officials will be accountable if they can engage stakeholders in the process of public service and policy.

This study does not attempt to bridge these differences, but takes another aspect of accountability that is not included in the debate above, namely public policy accountability.

\section{Accountability in Public Policy Implementation Perspective}

Policy implementation is one of the stages in the public policy process that seeks to realize policy objectives. Public policy can be said to be accountable when the system is able to meet the policy objectives and cover the target group of the policy. In reality, many of the policies that have been designed by policy makers turned out that after the policies were implemented, they were unable to achieve both of them. This is caused by the implementation of policy not as simple as thought, as stated by Goodnow (2004) about the political-administrative dichotomy. Therefore, policy implementers need to be involved in the process of policymaking so that the policy objectives are not reinterpreted by their implementers, as is the focus of the modern perspective of public administration.

The accountability of policy implementers can be understood differently from the development of public policy implementation studies. The development of this study includes three generations, namely first generation, second generation, and third-generation (Googin et al., 1990). The first generation of policy implementation focuses more on a single authoritative decision, either at a single location or at multiple sites. In this case, the successful implementation of policies or the successful achievement of policy objectives are less likely to be replicated to other locations or places, so that policy accountability in this generation cannot be used as a model or framework of public policy accountability.

The second generation public policy implementation study seeks to overcome weaknesses in the previous generation of implementation with the development of analytical frameworks to guide research on the complex phenomenon of policy implementation. In this generation has given birth to factors that influence the success of a 
public policy implementation, which Goggin et al. (1990) has concluded that all of these second generation studies focused on the same predictor variables: policy form and content; organizations and their resources; and people - their talents, predispositions, and their interpersonal relationships, including patterns of communication. Public policy accountability in the generation of policy implementation studies has enabled replication in other locations or places.

The third generation of policy implementation studies emerged to perfect the two previous generations by building a model of the implementation process that integrates the major concerns and variables of the top-down and bottom-up research traditions into a single framework. The principal aim of third-generation research is to shed new light on the implementation of behavior by explaining why that behavior varies across time, policies, and units of government (Goggin et al., 1990). This generation gave birth to a comprehensive model that shows not only predictor variables but also intervening variables. Accountability of public policies based on this generation can be replicated in other locations by taking into account various variations that might influence the implementation of public policies.

\section{Cross-Sector Collaboration: A Strategy of Public Policy Accountability}

Policy implementation, which is one of the stages in the public policy process, is no longer possible to be understood as the end of the policy formulation process. Policy implementation, however, is a complex process, as mentioned previously. This complexity can also refer to the number of actors or stakeholders, both individuals and organizations involved in the process of policy implementation, of which there are those who have direct, competitive, and even contradictory interests (Goggin, 1990; Hill \& Hupe, 2002). In addition, this complexity also demonstrates the difficulty of public policy accountability and implementers. Therefore, a synergy between stakeholders involved in policy implementation is a fundamental part of the achievement of policy performance. Such synergy can be done through a cross-sector collaboration strategy.

Collaboration between sectors, according to Bryson, Crosby, \& Stone (2006), "as the linking or sharing of information, resources, activities, and capabilities by organizations in two or more sectors to achieve jointly an outcome that could not be achieved by 
organizations in one sector separately". Based on this understanding, this collaborative model shows the use of important resources for achieving an outcome and carried out by organizations from across sectors. This also shows that this collaboration model uses resources effectively and efficiently in the delivery of policies and public services. The policy model in this study is adapted from the cross-sector collaboration model introduced by Bryson, Crosby, \& Stone (2006). The model includes initial conditions, process components, structure and governance, contingencies, and constraints that will produce outcomes and accountability.

\section{Research Method \\ Location}

This research was conducted in the district of Bone, South Sulawesi Province. The location determination is based on the consideration that Bone is one of the vast and varied food-producing regions in South Sulawesi Province (BPS, South Sulawesi in Figures, 2015).

\section{Design and Research Strategy}

The design of this study is qualitative with a case study research strategy. This research design aims to uncover the implementation of food security policies based on the context. In this case study, the research strategy applied was the explanative type (Yin, 2000).

\section{Informants}

The determination of informants in the study was carried out purposively, those who were considered to have competence in the context of implementing food security policies. Such a decision is based on an assessment of the expert (or the researcher himself) for a particular purpose or situation (Neuman, 1997). The informants in this study are: a) Head of Bone Regency; b) Officials and employees of the Office of Food Security; c) Members of Local Parliament; d) Business parties in the food sector, and e) farmers groups; f) people as consumers. 


\section{Data Collection Techniques}

In this study, data collection techniques used were observation, interviews (questionnaires), in-depth interviews, focus group discussions, and documents. Observations were made mainly on tangible objects, such as processing activities before and after harvest. In-depth interviews were conducted with the informants mentioned above, while the documentation technique was to collect documents in the form of regulations, journals and research results related to this research.

\section{Data Analysis}

Data processing techniques went through data reduction, data presentation, and drawing conclusions/verification (Miles and Hubeman, 1992), and data analysis applied pattern matching and time series analysis techniques.

\section{Results and Discussions}

\section{Performance of Food Security Policy in Bone Regency}

Food is a basic need for humans. This is one of the human rights, as guaranteed in the 1945 Constitution as a primary component to create quality human resources. Given the importance of the issue of providing food for the community, the government has adopted various policies and programs aimed at increasing food production. One of the efforts made is to increase food production, through programs such as intensification, identification and rehabilitation of food crops. These efforts have borne fruit with the achievement of food selfsufficiency, especially rice in 1984.

Through the implementation of these intensification, identification and rehabilitation programs, food crop production continued to increase until 1996. However, after that period, per capita production of various types of foodstuffs, including rice dropped dramatically even the per capita food production rate in 2006 was lower than the output of the previous ten years, in 1996 (BPS, 2006). This problem occurs because the productivity of agricultural land, which has been declining, is also triggered by various government policies. The policies in the agricultural sector of rice seemed not to support the farmers, for example, the lack of fertilizer subsidies and the determination of low grain prices. As a result, rice farming is increasingly unprofitable for farmers, and this led farmers' interest in rice farming and rice production declined. 
Based on the data from the Central Bureau of Statistics (BPS) in 2017, the level of rice consumption reached $114.6 \mathrm{~kg}$ per capita per year and is the highest level of consumption of food commodities. This consumption has increased compared to the 2013 rice consumption of $102 \mathrm{~kg}$ per capita. Consumption of rice per capita is twice as high as Japan, which reaches $50 \mathrm{~kg}$ per capita per year, whereas Korea consumes only $40 \mathrm{~kg}$ per capita per year. For Malaysia and Thailand, the rise consumptions are $70 \mathrm{~kg}$ and $80 \mathrm{~kg}$ per capita per year, respectively. The overall world rice consumption per capita is only around $60 \mathrm{~kg}$ per capita per year. This shows that the importance of food security is a government priority.

This food security policy is based on local food, consumed by local people in accordance with the potential and local wisdom of the region. This puts a consideration as Indonesia has a diverse natural wealth of agriculture in each region. One area, Bone Regency is a food crop-producing region in South Sulawesi (BPS, 2017). Geographically, the landscape of Bone regency consists of forest areas, other use areas, plantation, land owned and settlements. The condition is perfect for growing food crops such as rice, corn and soybeans. Recently, the amount of rice production is still relatively high compared to other types of food plants. For more details can be seen in the following table:

Table 1

Plant Area, Harvest Area, Production and Productivity of Bone Regency 2016 - 2018

\begin{tabular}{ccccccc}
\hline No & $\begin{array}{c}\text { Types of } \\
\text { Commodities }\end{array}$ & Year & $\begin{array}{c}\text { Planted } \\
\text { Area }\end{array}$ & $\begin{array}{c}\text { Harvested } \\
\text { Area }\end{array}$ & Production & Productivity \\
\hline & & & $\mathbf{( H a )}$ & $\mathbf{( H a )}$ & (Ton) & (Kw/Ha) \\
\hline 1 & Paddy & 2016 & 241.945 & 182.906 & 1.058 .812 & 57.888 \\
\hline & & 2017 & 233,230 & 233,230 & $1,228,348$ & 57.909 \\
\hline & 2018 & 208,119 & 208.71 & 1.207 .187 & 57.859 \\
\hline & & & & & 55.996 \\
\hline 2 & Corn & 2016 & 77.274 & 67.824 & 379.789 & 55.533 \\
\hline & & 80.442 & 76.431 & 424.441 & 56.120 \\
\hline & & 2018 & 69.994 & 71.991 & 424.445 & 18.490 \\
\hline 3 & Soybean & 2016 & 9.270 & 9.141 & 13.881 & 19.225 \\
\hline & & 2017 & 6.876 & 6.741 & 12.959 & 19.415 \\
\hline
\end{tabular}

Source: Department of Agriculture Food Crops \& Horticulture, Bone Regency, 2018.

Based on the figure above, the production of food plants in Bone Regency is quite large. Some food commodities such as rice, maize and soybean have high production where rice becomes the most significant production in 2018, reaching 1,207,187 tons with a productivity of $57,859 \mathrm{Kw} / \mathrm{Ha}$. Then it was followed by corn production, at 424,445 tons 
with a productivity of 56,120 and soybean, which reached 13,047 with a productivity of 19,415 .

Nevertheless, the production and productivity of these three food crops experienced fluctuations from 2016 to 2018. These fluctuations indicate that the performance of food security policies in Bone Regency has not been maximized. This is due to various problems such as the change of land use that causes a decrease in the amount of land, the availability of fertilizer for farmers and crop failure. Various programs to increase productivity and quality of food crops carried out by the government have not shown an optimal result. Policy intervention from the government is required.

Based on the data of BPS (2019), in 2018, the percentage of rice harvested Bone District contributed $15 \%$ of the harvested rice area in South Sulawesi Province, which reached 1,162,754 ha. Likewise, the commodity of corn and soybeans also contributed significantly to the area of harvest and production in South Sulawesi. The amount of national paddy and paddy rice production in 2018 reached 83,037,000 tons and the production has continued to increase since 2014. The details is presented in the following table:

Table 2

Total Production, Land Area and National Rice Productivity The year 2014 - 2018

\begin{tabular}{|c|c|c|c|c|c|c|c|}
\hline \multirow{2}{*}{ No. } & \multirow{2}{*}{ Komoditas } & \multicolumn{5}{|c|}{ Tahun } & \multirow{2}{*}{$\begin{array}{c}\text { Pertumbuhan } \\
2017 \text { thdp } 2016 \\
(\%) \\
\end{array}$} \\
\hline & & 2014 & 2015 & 2016 & 2017 & $2018^{1)}$ & \\
\hline \multirow[t]{4}{*}{1} & Padi & & & & & & \\
\hline & Produksi ( 000 Ton) & 70,846 & 75,398 & 79,355 & 81,149 & 83,037 & 2.33 \\
\hline & Luas Panen $(000 \mathrm{Ha})$ & 13,797 & 14,117 & 15,156 & 15,712 & 15,995 & 1.80 \\
\hline & Produktivitas (Ku/Ha) & 51.35 & 53.41 & 52.36 & 51.65 & 51.92 & 0.52 \\
\hline \multirow[t]{4}{*}{2} & Padi Sawah & & & & & & \\
\hline & Produksi (000 Ton) & 67,102 & 71,766 & 75,483 & 77,366 & 78,819 & 1.88 \\
\hline & Luas Panen $(000 \mathrm{Ha})$ & 12,666 & 13,029 & 13,985 & 14,556 & 14,721 & 1.13 \\
\hline & Produktivitas (Ku/Ha) & 52.98 & 55.08 & 53.97 & 53.15 & 53.54 & 0.73 \\
\hline \multirow[t]{4}{*}{3} & Padi Ladang & & & & & & \\
\hline & Produksi (000 Ton) & 3,744 & 3,631 & 3,872 & 3,783 & 4,179 & 10.47 \\
\hline & Luas Panen $(000 \mathrm{Ha})$ & 1,131 & 1,087 & 1,171 & 1,156 & 1,274 & 10.17 \\
\hline & Produktivitas $(\mathrm{Ku} / \mathrm{Ha})$ & 33.11 & 33.39 & 33.07 & 32.72 & 32.81 & 0.28 \\
\hline
\end{tabular}

Source: Central Bureau of Statistics, 2019 
As shown above, the national rice production and harvest area experienced an increase in production from 2014 to 2018, which was triggered by government intervention to achieve food self-sufficiency. Despite an increase in production and harvested area, on the other hand, the amount of rice productivity also fluctuates. National data on other food commodities such as corn also showed an increase in both the amount of production and productivity. In 2018 corn production will reach 30,056,000 tons with productivity of 52.41, while soybean commodity tends to fluctuate. This can be seen in the table below:

Table 3

Total Production, Harvest Area and Productivity of Palawija in Indonesia The year $2014-2018$

\begin{tabular}{|c|c|c|c|c|c|c|c|}
\hline \multirow{2}{*}{ No. } & \multirow{2}{*}{ Komoditas } & \multicolumn{5}{|c|}{ Tahun } & \multirow{2}{*}{$\begin{array}{c}\text { Pertumbuhan } \\
2018 \text { thdp } 2017 \\
(\%) \\
\end{array}$} \\
\hline & & 2014 & 2015 & 2016 & 2017 & $2018^{1)}$ & \\
\hline \multirow[t]{4}{*}{1} & Jagung & & & & & & \\
\hline & Produksi (000 Ton) & 19,008 & 19,612 & 23,578 & 28,924 & 30,056 & 3.91 \\
\hline & Luas Panen $(000 \mathrm{Ha})$ & 3,837 & 3,787 & 4,444 & 5,533 & 5,734 & 3.64 \\
\hline & Produktivitas (Ku/Ha) & 49.54 & 51.78 & 53.05 & 52.27 & 52.41 & 0.27 \\
\hline \multirow[t]{4}{*}{2} & Kedelai & & & & & & \\
\hline & Produksi (000 Ton) & 955 & 963 & 860 & 539 & 983 & 82.39 \\
\hline & Luas Panen $(000 \mathrm{Ha})$ & 616 & 614 & 577 & 356 & 680 & 91.22 \\
\hline & Produktivitas (Ku/Ha) & 15.51 & 15.68 & 14.90 & 15.14 & 14.44 & -4.62 \\
\hline
\end{tabular}

Source: Central Bureau of Statistics, 2019

As presented above, there is an increase in the amount of land, production, and productivity of corn commodities in the period 2014 - 2018. For the soybean, it experiences fluctuation. Food security policies in Indonesia, especially for rice, corn and soybean commodities that have increased production were triggered by the national program UPSUS PAJALE (Special Efforts for Rice, Soybean Corn) which has been carried out from 2015 to 2019. This program is the main concern of the government through the Ministry of Agriculture to achieve food self-sufficiency in the three commodities. Even so, the performance of the government faces various problems that need to be resolved by the central and regional governments. For instance, the lack of irrigation network infrastructure, where much irrigation, both primary and secondary, is not appropriately handled. Second is the seed problem. Third, the availability of fertilizer is infiltrated by illegal fertilizer distributors who supply farmers with non-subsidized fertilizer. Fourth, related to the question of decreasing the number of workers. Fifth, agricultural extension programs are not yet optimal. 
Generally, what has been discussed above shows that the accountability of food security policies in Bone Regency is questionable. This is because the performance of this policy (productivity) in Bone Regency is lower than the performance of national policies. In addition, the richness of the three main foods remains stagnant even though the assistance of resources from the central government has increased significantly year by year.

\section{Cross-Sector Collaboration Process: Public Policy Accountability Strategy}

The cross-sector collaboration process developed by Bryson et al. (2006) focuses on several aspects, which include: a) Forging agreement; b) Building leadership; c) Building legitimacy; d) Building trust; e) Managing conflict; and f) Planning. The collaboration process is a strategy in creating food security policy accountability because this process is a synergy interaction between all stakeholders.

1. Forging agreement

Agreements designed in a collaborative process consist of formal and informal agreements. Formal agreements are important factors and have advantages in supporting collaboration accountability (Donahue, 2004). Therefore, the need for various initial agreements between stakeholders or changing agreements between them is very likely to occur. The results of this study revealed that the formal and informal agreements that were designed lack all elements and aspects of cross-sector collaboration. This is indicated by the limited mandate and role of actors such as the Food Crops Office, Horticulture and Plantation, the Food Security Agency, sub-district / village governments, agricultural extension workers, and also farmers' groups. The role and commitment of resources from the food security service, which is limited in number, causes the collaboration process not to run optimally. The agreement designed also did not regulate all aspects and rules of the game needed in collaboration to encourage policy accountability.

2. Building leadership

The role of formal leaders (building leadership) is an essential element in the crosssector collaboration process. The role of the leader consists of sponsors and champions. Sponsors are individuals who have authority and access to resources even though they are not involved intensively in the collaboration process. While champions are 
individuals who intensively focus on the process of collaboration and achieving the goals of the collaboration.

Cross-sector collaboration in the implementation of food security policies in Bone District, which holds a key role as the leader of the collaboration is the Regent as the sponsor, the Head of the Food Crops, Horticulture and Plantation Office and the head of the Food Security Agency as the champion.

The Head of Bone Regency has the authority to provide resources in the crosssector collaboration process as well as regional leaders. The authority held in using available resources becomes an important indicator that supports the successful implementation of the policy. In fact, the role and commitment of the regent as a sponsor for success tend to be lacking. This is indicated by the support of policies and the low budget allocated for food security policy program activities. The level of commitment of sponsors is one of the keys to successful cross-sector collaboration in food security policies in Bone District.

While the champion in this cross-sector collaboration is the head of the Department of Food Security, who is involved and contributes greatly in the process of implementing food security policies, such as organizing and monitoring/evaluating the implementation of plots for food crops and the socialization of diversification of food consumption in Bone Regency. The role of the head of the department of food security in this policy as a matter of fact tends to be small and less active so it does not contribute greatly to the success of the policy performance. The role of the champion is very important because as the leader of the government organization, the policy organizer has the authority and access to resources. Though collaboration across sectors has a high chance of success and success when formal and informal leadership includes sponsors and champions at various levels demonstrates commitment and alignment with policy (Bryson, 2006).

3. Building legitimacy

The dimension of building legitimacy in relation to cross-sector collaboration in implementing food security policies is a process of creating legitimacy among stakeholders who collaborate to be trustworthy and to be expected to be credible to the interests of collaboration. Efforts to build legitimacy between the Food Crops Office, 
Horticulture and Plantations, the Food Security Agency, sub-district / village governments, agricultural extension workers, farmers' groups are not working as they should. Though this factor is crucial in creating policy accountability involving various actors in its implementation.

4. Building trust

The relationship of trust among stakeholders across sectors is the essence of collaboration. Stakeholders build trust through sharing information and knowledge and carrying out agreed commitments. Conversely, if a commitment is not carried out can cause distrust of one another among stakeholders that can hamper policy accountability. The food security policy based on cross-sector collaboration in Bone district shows that stakeholders carry out information and knowledge sharing activities about programs and activities related to food security.

The emergence of trust is demonstrated by a mutual trust with each other that each stakeholder will carry out his role and duties. The Department of Food Security believes that stakeholders such as agricultural extension workers are able to encourage farmers to be productive, as is the government's belief that farmer groups can change their mindset to abandon traditional farming methods to more modern technology. Although the majority of stakeholders have confidence in each other, the fact is that there are still stakeholders who lack trust in other stakeholders to be able to carry out commitments as a form of trust that is built. The process of building trust is not yet optimal because the government does not yet fully believe that people's mindsets can change so that there is a significant increase in food crop production.

5. Managing conflict

Conflicts in collaboration can occur when there are different goals and expectations of stakeholders that encourage them to collaborate. Managing conflict is one of the important things in collaboration. In addition, conflicts will arise if the level of the collaborating organization is not equal. Cross-sector collaboration in food security policy in Bone Regency never has before experienced major disputes between the stakeholders involved. Each stakeholder carries out tasks according to their role in implementing food security policy. 
6. Planning

To carry out a collaborative process successfuly, careful planning is needed as an effort to achieve goals. Cross-sector collaboration in the implementation of food security policy in Bone Regency shows that planning has been arranged and structured by articulating the mission, goals, objectives, roles and responsibilities of each stakeholder in cross-sector collaboration. In terms of planning, the government has set a goal, which is to diversify food consumption through food security policy in order to reduce the level of rice consumption. Besides planning, it also includes the roles and responsibilities of the stakeholders involved. The program of activities that have been set by the government to achieve these objectives include: a) the use of the yard for local food crops; b) Socializing diversification of community food consumption so that rice consumption can be reduced by other food crops.

\section{Conclusion}

Public policy performance is a key indicator to assess the accountability of public officials as they determine and implement public policy. The accountability of food security policies in Bone Regency is still not high because food productivity has stagnated and fluctuated. However, the three types of local food (rice, corn, and soybean) have always received attention from the central government, providing large assistance for the development of these commodities each year. This is caused by the process of collaboration between sectors, where a public policy accountability strategy does not run effectively. Therefore, the government needs to be the initiator and facilitator in gathering and encouraging collaboration among all stakeholders.

\section{References}

Bryson, John M., Crosby, Barbara C., \& Stone, Melissa Middleton. (2006). The design and implementation of cross-sector collaborations: propositions from the literatur. Public Administration Review. Desember 2006. Special Issue

Bovens, M. (2005). Public accountability. In The oxford handbook of public management. Ferly E. Lynne L, Pollitt C. (Editors). Oxford: Oxford University Press.

Denhardt, Janet V. and Denhardt, Robert B. (2003). The Public service: service, not steering. USA: M.E. Sharpe, Inc. 
Dwivedy, O.P \& Jabbra, Joseph G. (1988). Public service responsibility and accountability. In Dwivedy, O.P \& Jabbra, Joseph G. (Editors). Public service accountability: A comparative perspective. USA: Kumarian Press, Inc.

Erkkila, Tero. (2007). Governance and accountability - A shift conceptualization. FAQ Spring

Goggin, M. L., Bowman, A., Lester, J,. \& O’Toole, L. (1990). Implementation theory and practice: toward a third generation. Illinois: Foresman and Company.

Goodnow, Frank J. (2004). The study of administration. in shafritz, Jay M. et.al (2004). Classics of public administration (5 ${ }^{\text {th }}$ Edition). USA: Wadsworth/Thomson.

Hill, Michael \& Hupe, Peter. (2002). Implementing public policy: governance in theory \& practice. London: SAGE Publication Ltd.

Miles, M.B., Huberman A.M., \& Saldana, J. (2014). Qualitative data analysis: A methods sourcebook. USA: Sage Publication. Inc.

Mulgan, R. (2000). Accountability: An ever-expanding concept? Public Administration, 78 (3).

Neuman, W. Lawrence. 1997. Social research methods: qualitative and quantitative approaches. $\left(3^{\text {rd }}\right)$, USA: Allyn and Bacon.

Pressman, Jeffrey L. \& Wildavsky, Aaron (1984). Implementation (3 ${ }^{\text {rd }}$ Edition, Expanded). California: University of California Press.

Smith, Kevin B. \& Larimer, Christopher W. (2009). The public policy theory primer. USA: Westview Press. 